\title{
Extended resection of the trachea in a patient with cicatricial tracheal stenosis after tracheostomy complicated with esophageal-tracheal fistula and extensive defect of the frontal tracheal wall
}

\author{
Shukhrat Khudaybergenov, Otabek Eshonkhodjaev, Sodiqjon Abdusalomov, Bakhrom Amanov \\ Republican Specialized Centre of Surgery Named After Academician V.Vakhidov, Tashkent, Uzbekistan
}

Kardiochirurgia i Torakochirurgia Polska 2017; 14 (1): 55-58

\begin{abstract}
We present a case of one-stage radical surgical treatment of a 24-year-old female patient with cicatricial granulating tracheal stenosis after tracheostomy complicated by esophagealtracheal fistula and an extensive defect of the anterior wall of the trachea after numerous unsuccessful attempts to correct the narrowing of the trachea and eliminate the fistula by endoscopic and open surgical techniques. The patient underwent extended tracheal resection with end-to-end anastomosis with liquidation of the esophageal-tracheal fistula and elimination of the defect of the anterior wall of the trachea by cervical access.
\end{abstract}

Key words: thoracic surgery, tracheal stenosis, tracheal resection, fistula.

\section{Introduction}

Cicatricial tracheal stenosis until recently was a rare surgical disease. Its causes are varied, but in all cases it is characterized by the appearance of local acute or chronic inflammatory changes occurring in the wall of the trachea. These changes lead to degradation over time and pathological restructuring of constituent structures and their replacement by fibrous tissue. They are often combined with the phenomena of general and local tissue hypoxia, which predispose to ischemic necrosis and ulceration of the mucous membrane of the trachea, and the local development of chondrite tracheomalacia. Morphological changes during prolonged mechanical ventilation vary - from epithelial damage with the formation of transmural necrosis to erosion of the tracheal wall to form a fistula between the esophagus and the trachea [1, 2].

A pathogenetic factor and a trigger mechanism leading to development of the disease is damage to the wall of the trachea, followed by infection and the development of a purulent-necrotic process the outcome of which is the formation of a scar [3].

\section{Streszczenie}

Przedstawiamy przypadek jednoetapowego, radykalnego zabiegu chirurgicznego przeprowadzonego u 24-letniej pacjentki z bliznowatym zwężeniem tchawicy z ziarninowaniem po tracheotomii powikłanej przez przetokę przełykowo-tchawiczą oraz z rozległym ubytkiem przedniej ściany tchawicy po licznych nieudanych próbach korekcji zwężenia tchawicy i przetoki z zastosowaniem technik endoskopowych i chirurgii otwartej. Pacjentkę poddano rozległej resekcji tchawicy z dostępu szyjnego z zespoleniem koniec do końca i likwidacją przetoki przełykowo-tchawiczej oraz ubytku przedniej ściany tchawicy. Słowa kluczowe: torakochirurgia, zwężenie tchawicy, resekcja tchawicy, przetoka.

Modern respiratory and tracking equipment and development of a variety of pharmacotherapy in an intensive care unit have allowed the patient to be protected from a critical and grave condition for a long time, sometimes up to several weeks or even months. Conducting prolonged mechanical ventilation in some cases creates conditions for the formation of irreversible changes in the tracheal wall and development of tracheal lumen narrowing, in some cases complicated by a tracheo-esophageal fistula [4-6].

At present in most cases trauma of the trachea is iatrogenic in nature and most often occurs during artificial lung ventilation (ALV), even more likely during prolonged mechanical ventilation through the endotracheal tube or tracheostomy tube, or as a complication during application of tracheostomy or at the time of intubation [7-10].

The aim of the study was to present the results of the successful one-stage radical surgical treatment of patients with cicatricial granulating tracheal stenosis after tracheostomy complicated by esophageal-tracheal fistula after numerous unsuccessful attempts to correct the narrowing of the trachea and eliminate the fistula by endoscopic and open surgical techniques. 


\section{Case report}

A 24-year-old female patient was diagnosed with scargranulating tracheal stenosis after tracheostomy complicated by esophageal-tracheal fistula. On August 20th 2014 as a result of a car accident the patient had severe concomitant injury. In the postoperative period for 22 days the patients underwent mechanical ventilation. After waking up in the early rehabilitation period the patient exhibited stridor. On suspicion of tracheal stenosis the patient was transferred to the ENT clinic, where she underwent tracheoplasty on the T-tube. However, in the postoperative period, the patient began to experience the phenomenon of aspiration while taking liquid food. At the control examination ENT doctors revealed that after removing the T-tube on the rear wall of the trachea in the projection of

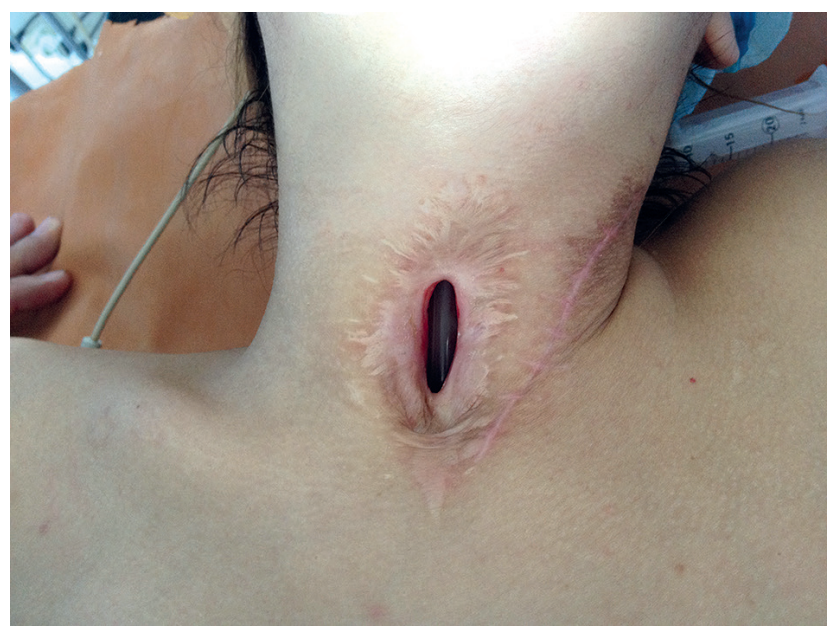

Fig. 1. Defect of the frontal wall of the trachea and the soft tissue on the neck after the earlier projected tracheoplasty. Pronounced postoperative scars on the neck

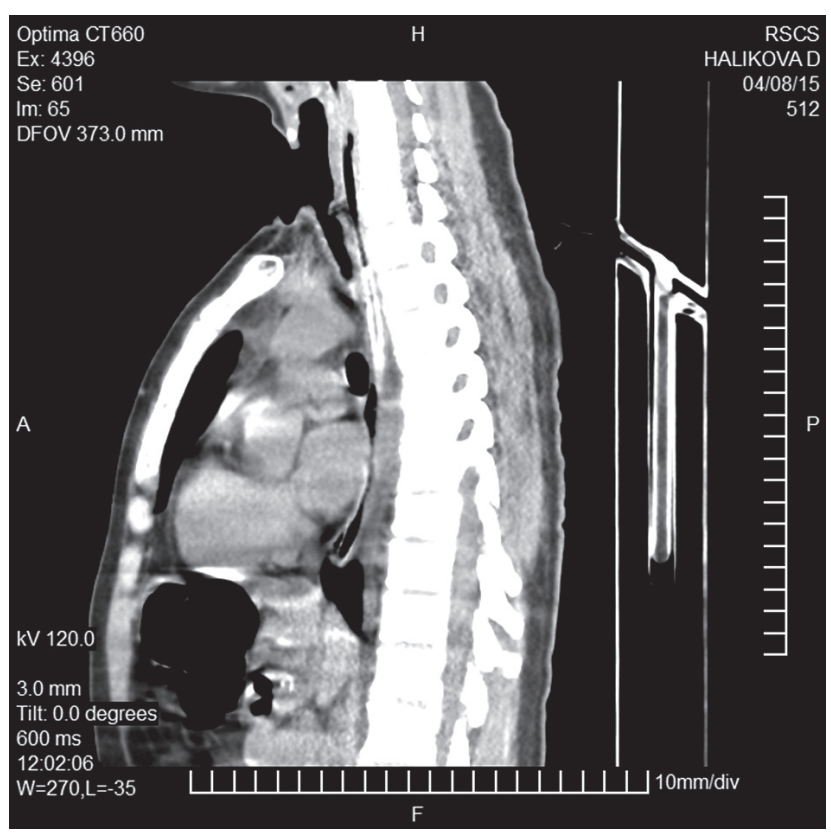

Fig. 2. Computed tomography. Defect of anterior wall of trachea, narrowing of the tracheal lumen, fistula tracheostomy a tracheo-esophageal fistula with a size of 3 to $5 \mathrm{~mm}$ was determined. Endoscopists performed installation of a nasogastric tube and laser photocoagulation of the fistula from the trachea side and from the side of the esophagus to cause the growth of granulation tissue which may contribute to the closure of the fistula. However, the control examination after 2 months by removing the T-tracheal tube despite nasogastric enteral nutrition and performance of laser coagulation showed that the fistula hole was not closed. The patient was directed to the surgeons for open surgery for closing the tracheo-esophageal fistula. In November 2014 the patient underwent the operation of liquidation of the esophageal-tracheal fistula by cervical access. The medical records indicated that was separation of the fistula by suturing and ligation, followed by placing a flap of sternocleidomastoid muscle between the esophagus and the trachea in the projection of the eliminated fistula channel. However, the early postoperative period was marked by the failure of the suture, recurrence of the fistula with an increase in its size and suppuration of postoperative neck wounds. The patient within 6 months had aspiration respiratory complications of the fistula. In April 2015 the patient came to our center. Complaints of the patient referred to: dyspnea on exertion, the presence of a tracheostomy tube, cough with difficult expectoration, the presence of a nasogastric tube, the inability to eat by mouth, and inability to breathe through the natural airway. The patient was evaluated by bronchoscopy and computed tomography. The studies found:

1) defect of the frontal wall of the trachea and the soft tissue on the neck after the earlier projected tracheoplasty, size 15 to $35 \mathrm{~mm}$,

2) pronounced postoperative scars on the neck after suffering several operations of tracheoplasty attempts to eliminate the fistula and postoperative wound festering (Fig. 1),

3) scar-granulation narrowing of the trachea in the projection of tracheostomy and progression of the tracheal stenosis in 20 min after the removal of the T-stent due to lack of skeleton (frame) of the trachea and the presence of tracheomalacia (Fig. 2),

4) the presence of a fistula channel between the cervical trachea and esophagus with the size of $6 \times 8 \mathrm{~mm}$ (Fig. 3), 5) right-side aspiration pneumonia, purulent bronchitis.

\section{Discussion}

The patient underwent preoperative anti-inflammatory therapy, antibiotic therapy, and remedial bronchoscopy. On July 5,2014 , the patient underwent the following operation: one-stage extended tracheal resection with end-to-end anastomosis with liquidation of the esophageal-tracheal fistula and elimination of the defect of the anterior wall of the trachea by cervical access. $5.5 \mathrm{~cm}$ of the affected part of the upper and middle third of the trachea was resected. Diastasis between the stitched caudal and cranial ends was $6 \mathrm{~cm}$ (Fig. 4). The difference between this type of resection carried out in the treatment of isolated cicatricial tracheal 


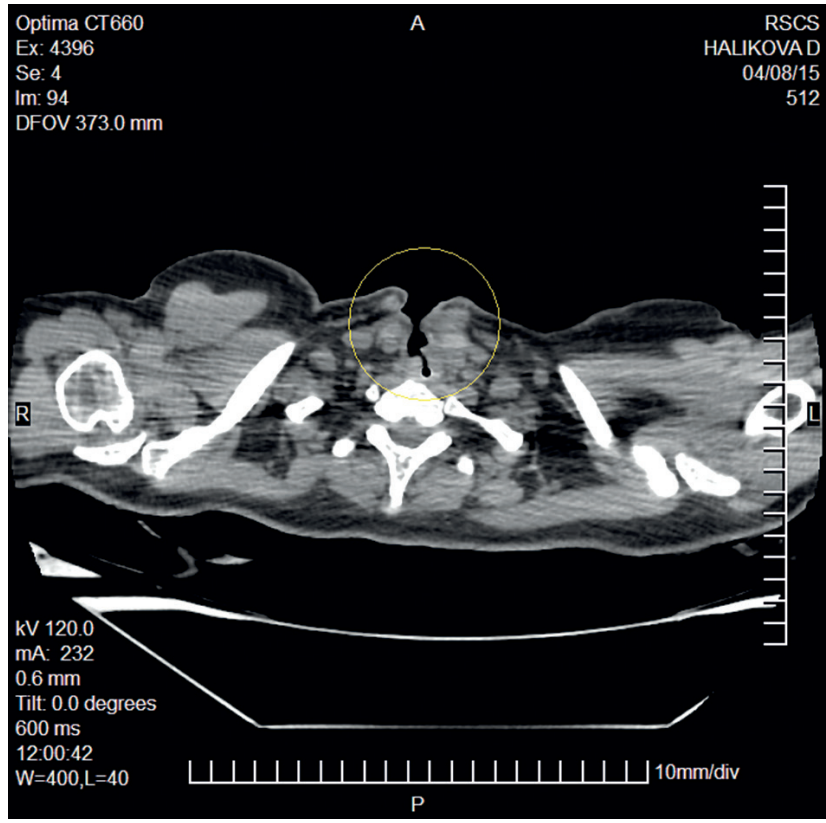

Fig. 3. Computed tomography. Tracheo-esophageal fistula on the back wall of the stoma

stenosis without esophageal-tracheal fistula is that only the cartilaginous part of the tracheal wall is excised and removed and the membranous wall of the trachea is left in the zone of the esophageal-tracheal fistula to create an excess of tissue to perform closure of the fistula (Fig. 5). The fistula is sutured by interrupted absorbable stitches (Fig. 6). Also different is the method of forming the tracheal anastomosis: in circular resection of the trachea in patients with cicatricial stenosis we usually apply the technique of anastomosis with the formation of a posterior membranous wall by continuous Biosyn 3.0 suture and with interrupted sutures on the side (angle) and front wall. But in formation of the anastomosis in patients with cicatricial stenosis complicated with esophageal-tracheal fistula there is a risk of inconsistency of the esophageal fistula's sutures that can be complicated by fatal failure in the transition to the tracheal anastomosis. In order to create a more solid

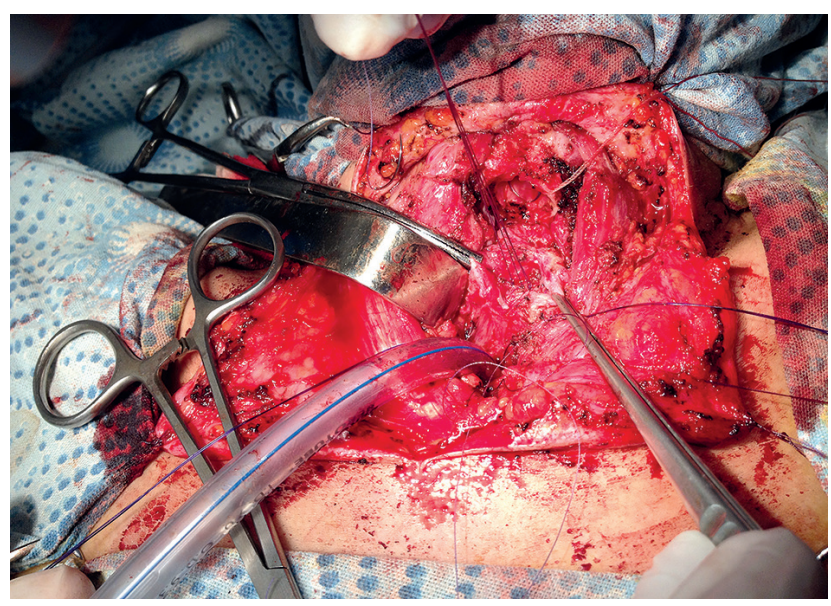

Fig. 6. Fistula stitched by interrupted absorbable sutures

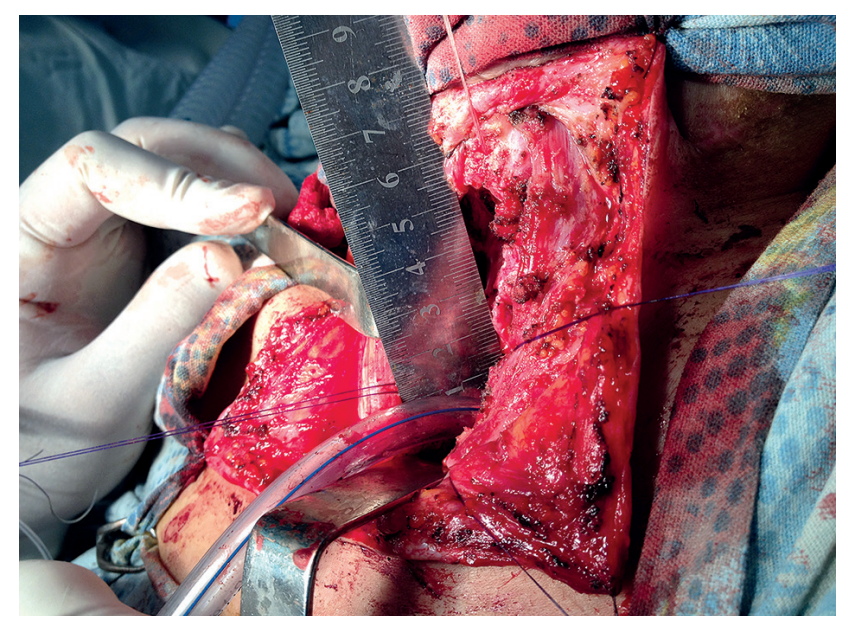

Fig. 4. Diastasis between cranial and caudal part after resection of the trachea

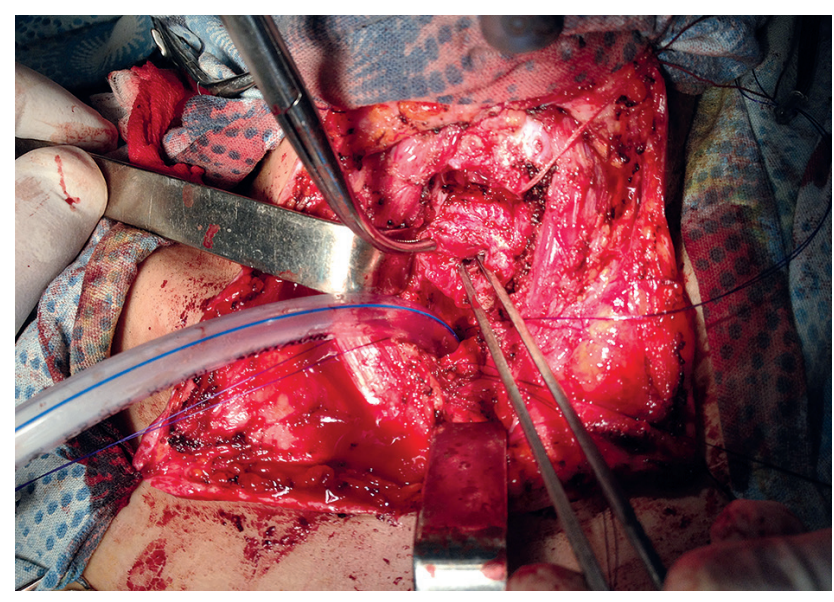

Fig. 5. Fistula hole. Left tissue of the membranous part of the trachea around the fistula after resection of the cartilaginous part

and sealed back wall of the anastomosis we used the interrupted nodal Biosyn 3.0 seams on the back, front and side walls (Figs. 7-9). In order to minimize the tension in the area of the anastomosis seam we mobilized the trachea

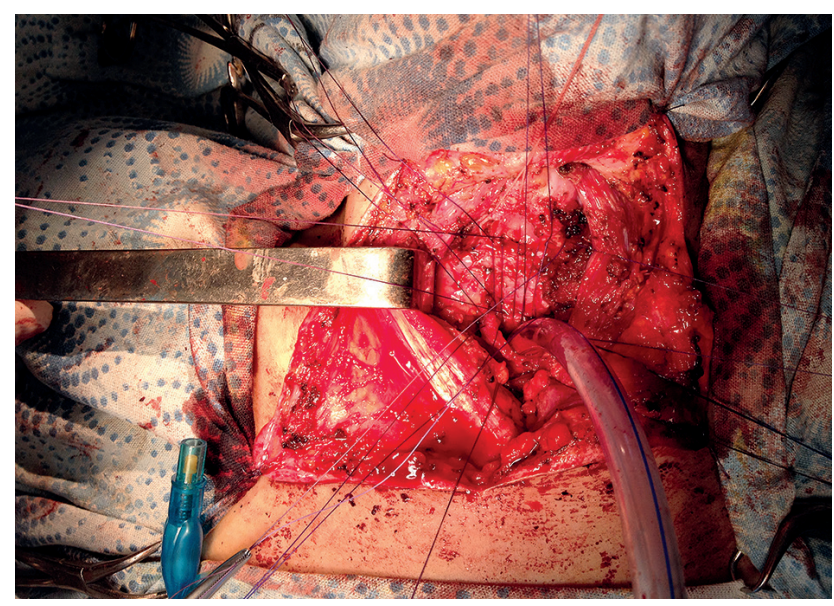

Fig. 7. Shunt-breathing. Interrupted sutures on the back wall of the anastomosis 


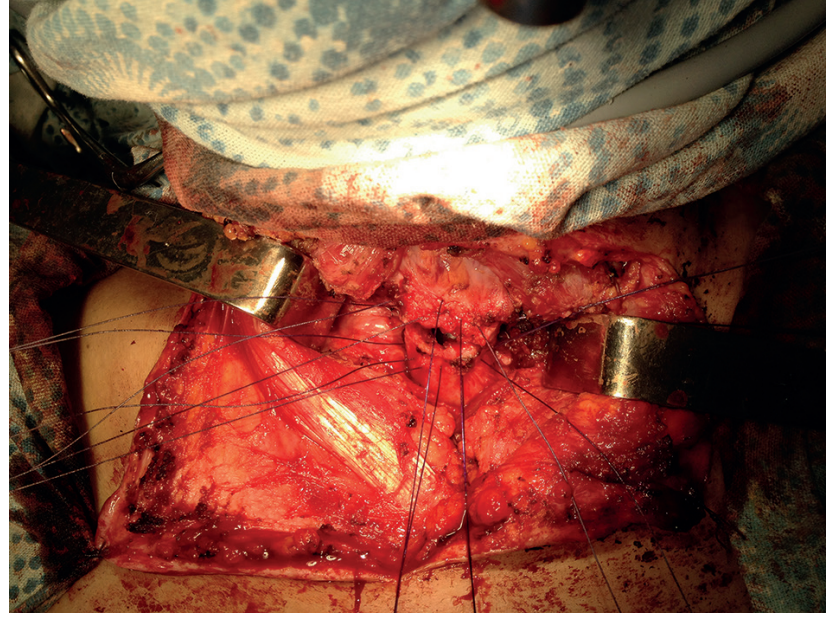

Fig. 8. Shunt-breathing removed and orotracheal intubation tube inserted into the lower part of the trachea. Anterior wall of anastomosis

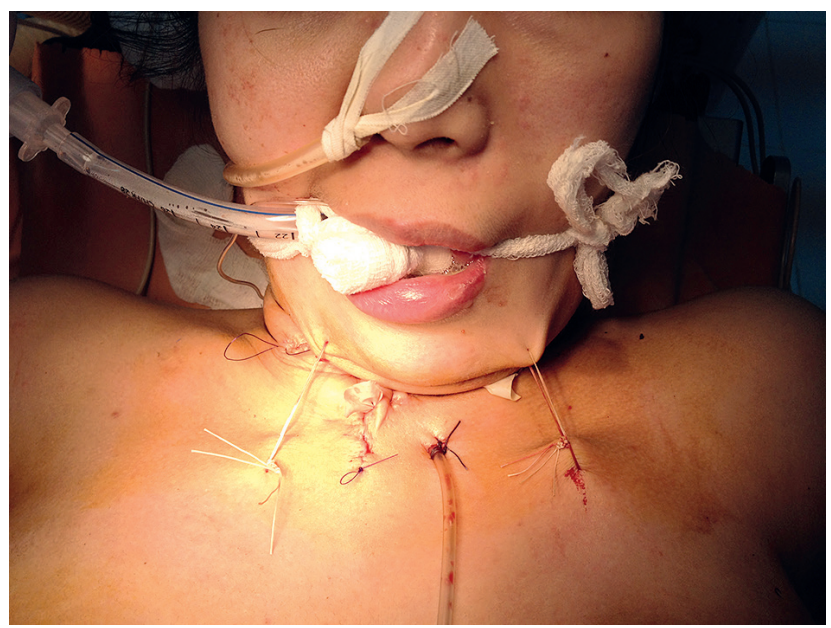

Fig. 10. Head temporarily fixed in position at the chest wall

over the projection of the middle and lower third up to the bifurcation of the trachea with pulling in the cranial direction using tight ligatures. Also we used the technique of temporarily fixing the head in position bringing it to the chest wall and suturing the skin of the chin on the chest for 14 days to eliminate the sharp head-up movement during sleep and the load on the anastomosis (Fig. 10).

The postoperative period was uneventful. On the $7^{\text {th }}$ day after the operation endoscopic follow-up was carried out. The anastomotic area was sealed. The gastric feeding tube was removed on the $14^{\text {th }}$ day. Also after 2 weeks fixing lead sutures on the chin were removed. The patient was able to lift the head freely, and was breathing through the natural airway, with clear phonation. Feeding was restored through the mouth.

The patient underwent routine endoscopic examination at 1 month, 3 months and 5 months after surgery. In the area of the anastomosis bronchoscopy showed a smooth whitish thin line not protruding beyond the cartilaginous rings of the trachea. The lumen of the trachea in the zone of the anastomosis was without restriction or distortion.

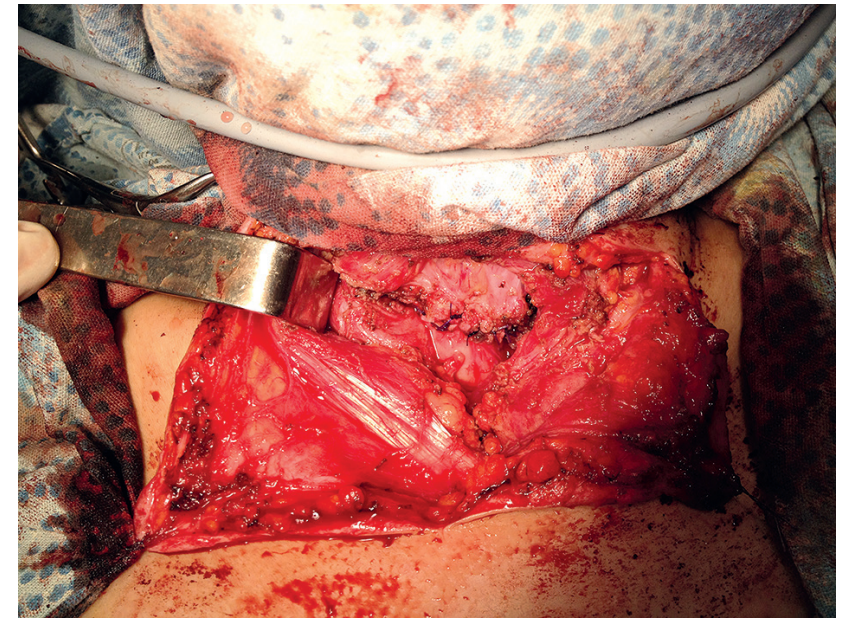

Fig. 9. Completed tracheal anastomosis

\section{Conclusions}

Tracheal resection with simultaneous liquidation of tracheoesophageal fistula with stenosis of the trachea and defect after laryngotracheoplasty is the method of choice which can radically heal the patient at one stage after unsuccessful attempts to liquidate the tracheoesophageal fistula. The operation belongs to the category of complex reconstructive surgery and requires well-coordinated work of specialists - thoracic surgeons, endoscopists and anesthesiologists - and should be performed in specialized clinics.

\section{Disclosure}

Authors report no conflict of interest.

\section{References}

1. Mińambres E, Burón J, Ballesteros MA, Llorca J, Muńoz P, González-Castro A. Tracheal rupture after endotracheal intubation: a literature systematic review. Eur J Cardiothorac Surg 2009; 35: 1056-1062.

2. Parshin VD, Vyzhigina MA, Rusakov MA, Volkov AA, Parshin VV. Surgical treatment of stenosis of thoracic part of trachea in combination with rupture of trachea and left main bronchus. Khirurgiia (Mosk) 2012; 4: 70-72.

3. Kotiv BN, Popov IB. Possibilities of surgical treatment of cicatricial stenosis of trachea. Vestn Khir Im II Grek 2013; 173: 28-31.

4. Brichet A, Ramon P, Marquette $\mathrm{CH}$. Post-intubation tracheal stenosis and ruptures. Réanimation 2002; 11: 49-58.

5. Fiala P, Cernohorský S, Cermák J, Pátek J, Krepela E, Moucková M. Tracheal stenosis complicated with tracheoesophageal fistula. Eur J Cardiothorac Surg 2004; 25: 127-130.

6. Tatur AA. Diagnostic and treatment of cicatricial stenosis of trachea in combination of tracheoesophageal fistula. Military Medicina 2014; 1: 72-75.

7. Sarper A, Ayten A, Ozbudak O, Demircan A. Tracheal stenosis after tracheostomy or intubation. Tex Heart Inst J 2005; 32: 154-158.

8. Galluccio G, Lucantoni G, Battistoni P, Paone G. Interventional endoscopy in the management of benign tracheal stenoses: definitive treatment at longterm follow-up. Eur J Cardiothorac Surg 2009; 35: 429-433.

9. Han S. E-Comment: new technique in tracheal reconstruction. Interact Cardiovasc Thorac Surg 2009; 9: 449-449.

10. Krajc T, Janik M, Benej R, Lucenic M, Majer I, Demian J, Harustiak S. Urgent segmental resection as the primary strategy in management of benign tracheal stenosis. A single center experience in 164 consecutive cases. Interact Cardiovasc Thorac Surg 2009; 10: 1510-1514. 